\title{
Features of Corporate Relations Regulation in the System of Target Industrial-Financial Groups and other Unions in the Context of Transborder Collaboration
}

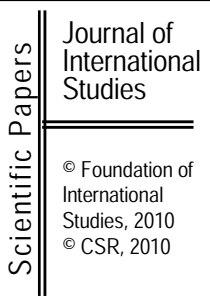

Mgr Olga Boryk

Associate professor of Economy enterprises department

Ternopil Institute of Social and Informational Technologies

borykolya@ukr.net

\begin{abstract}
An article is devoted to substantiation and determination of methods of the in-corporative and state adjusting of corporate relations on the Target Industrial-Financial Groups (TIFG) example; development of the most perspective directions of their introduction taking into account modern reality of economy of Ukraine and necessity of perfection of transborder collaboration efficiency.
\end{abstract} Submitted: February, 2010 $1^{\text {st }}$ revision: May, 2010 Accepted: June, 2010

Keywords: target industrial-financial groups, methods, state regulation, distribution of corporate profit, conflict of interests, corporate conflict.

JEL classification: L16, Q16, P2

\section{Problem rising in the general view and its copulas with the important practical tasks}

The Target Industrial-Financial Groups (TIFG) functioning in Ukraine exposes a complex of problems of corporate management, namely: choice of type of industrial-financial union; permission of conflict of participants' interests; choice of management charts by the real proprietors; deprivation of "little man" syndrome. The special reason of enterprises integration in the one corporate structure is an attempt to take advantage of potential gardenstuffs of integration without the hard centralization of control above resources. Intergoup relations are a weak point of TIFG that, as a result, can have negative phenomena, in particular: incomplete realization of integration effect; increasing of "distance" between the group projects and their practical realization; appearance of problem at the main enterprise TIFG in relation to the real levers of influencing on the group enterprises-members; absence of joint activity strategy; low level of reliable and efficient information about enterprises work. For the present practice of economy support in the corporate sector of Ukraine it has characteristics of forming specific motivation of managers and large shareholders, oriented mainly to the control of financial streams and destroying assets of guided enterprises in the shadow appeal, presence of substantial blanks in the legislative providing of defence for investors' rights. In case of these circumstances, it is not accidentally that development of home economic societies is accompanied by sharpening corporate conflicts. From the higher led infirmation it goes out that the development of corporate relations in the modern terms of Ukraine needs the weighed influence not only from the state side, but also from the TIFG participants. For this purpose it is necessary to define and systematize the set of the proper methods and facilities of the state and in-corporate reregulation, to find out expedient scopes of their application to the terms of the Ukrainian economy. 


\section{Analysis of the last researches}

In works of the Ukrainian scientists the state influence methods on the corporate sector of economy are mainly considered as their legal kind. D.V.Zadihaylo, O.R.Cibenco, G.V.Nazarova analyse the features of the legal regulation of the system of corporate management in Ukraine [2, p. 20-28]; O.M.Vinnic, V.S.Shcherbina explore the methods of the legal regulation of joint-stock relation which are based on the law [1, s. 8-10]. V.A.Evtushevsciy considers the state regulation of corporate sector through the prism of organizational administrative base of functioning corporations [3, s. 77-81]. The Russian scientific workers, in particular T.V.Cashanina, O.A.Sudarcova, explore intercommunication of the system of methods of the state and corporate regulation of economic relations $[4$, s. 8$12]$.

\section{Formulation of purposes of the article}

A purpose of article is determination of methods of the in-corporate and state regulation of corporate relations, development of the most perspective directions of their introduction taking into account modern reality of economy of Ukraine.

\section{Exposition of basic material of research}

A modern level of corporate relations development is characterized by wide ramified of corporate structures, intercommunication and interlacing economic processes in the different corporations. As a result the integrated corporate systems appear in which the network character of co-operations arises up, that is the possibility of agents of the system to come forward in a role of centers or elements, and the contradiction between interests of corporations and centers proper to them. As a result of this problems of complex management by the mutual relations of corporations and organizations-members taking into account all commodities and financial communications, that were practically realized, organizations of the subject's stimulation systems of mutual relations within the framework of an effect distributing processes became actual. It is clear that every enterprise aims to get greater part of shareable resources. As a rule, this results in the tendency of overstating requests on the necessary financial means, to the conflicts in case of distributing corporate facilities in TIFG. Problems of concordance of commodity financial mutual relations of corporations and organizations were considered within the framework of hieratic game theory, theories of multicritia choice, theories of the active systems, in particular, such its aspects, as incorporate structurization, stimulation and concordance of interests, projects concerted management. However, because of appearing of principally more difficult object of research existent models, methods and machineries of interest's concordance and multicriterion choice are not enough perfect for the practical use. The horizontal co-operations of corporate centers will be realized within the framework of contractual relations on the large agreements. The vertical co-operations of corporate center and integrated organizations will be realized in case of redistribution of effect between the members of one and the same corporation and decide a task of their interests concordance.

The mechanism of economic interest's concordance will be realized in the form of incorporate contracts and includes organization of such co-operations, as consolidation of profit from the sale or services in the corporate center and transmission of part of profit to organizations - to the elements of corporation. Development of management machineries by the intercorporate co-operations must be carried out taking into account the next features of these intercommunications: 
network character of co-operations - stipulates models invariation to the change of participant's role;

the opened character of network structure results in the necessity of different models development that save adequacy at any quantity of participants;

- the presence of contradictions between interests of corporations and centers predetermines a necessity of complex machineries of interest's concordance that take into account all co-operations, that are practically realized;

- the necessity of providing firmness of co-operations requires creation of effective mechanism of their stimulation that foresees the redistribution of effect.

Task of horizontal in-corporate agreement of interests is consisted in organization of horizontal in-corporate co-operations, macsimizing the criteria of the organizations efficiency, integrated in corporation. The concordance sphere engulfs the streams of capital, volumes of resources and commodities delivery that, circulate within the framework of corporation. Accordingly, the management parameters, in this case, are the volumes of the in-corporate financing and turnover. Incomes of organizations are the criteria of concordance efficiency that are included in TIFG.

Task of vertical in-corporate concordance of interests consists in organization of vertical in-corporate co-operations, macsimizing the criteria of corporate center and organizations efficiency, integrated in corporation. The concordance sphere engulfs the streams of investments and redistribution of income within the framework of IndustrialFinancial Groups (IFG). The criteria of concordance efficiency, from one side, are incomes and growth funds, that remain at disposal of organizations after the dividends payment to the proprietors (to the shareholders), from other side, sums of the dividends that the corporate proprietors (by shareholders) got. Task of horizontal intercorporate concordance of organizations interests is based on the management of the horizontal co-operations of organizations, that macsimize the criteria of firms' efficiency, which are included in different IFG. The concordance sphere engulfs the volumes of financing, deliveries of resources and commodities that circulate within corporations. The criteria of concordance efficiency are incomes of interactive corporations, levels to the total income of organizations that are included in the proper corporation. Directly, the realization of horizontal intercorporate cooperations concordance is carried out by metacentre, in a role of which the TIFG kernel comes forward.

The mechanism of vertical concordance is realized in the hieratic corporate system in the case when center, an organ of the TIFG management, co-ordinates activity of organizations, that belong to it, active elements (AE), with the help of its actions, and guided $\mathrm{AE}$, carrying out their realization, simultaneously decide the task of own criteria optimization. Methods of imperious influence of state organs on the processes of development of corporate sector of economy in this article are understood as methods of the state regulation of corporate relations.

The relations in TIFG contain the elements of various relations: household legal, civil legal, obligation, property, financial, labour, and organizational (actually administrative) and others like that. The purview of these relations contacts not only with the in-household of company (by the mutual relations between shareholders, managers and personnel), but also spreads on its relationships with the external surroundings (by other subjects of economy support, public authorities). The key factors of corporate relations are property separation and autonomous of their participants one from other, absence of any imperious plenary powers in relation to one another and legal equality. That's why; the state uses the methods of the private legal regulation in regard to the corporate organizations: autonomous decisions, coordination, recommendations and others like that. The private legal regulation is used with the purpose of defense of concrete person 's private interests as party to the corporate 
relations - actually company, its founders and organs of management, some shareholders, managers, creditors, hired workers and so on.

The basic methods of the state regulation of corporate relations in Ukraine can be legal, economic, administrative, which are directed on the creation processes, functioning and stopping TIFG activity. Accordingly, the subjects are Cabinet of Ministers of Ukraine, the Antimonopoly committee, Fund of state property of Ukraine, the State commission of securities and fund market, and also other public authorities. Objects: internal and external economic processes in TIFG.

\section{Conclusions of the given research and prospect of further researches}

Development in Ukraine the processes of redistribution of property testifies that for providing high efficiency of corporations activity it is necessary to look for the machineries of structural conflict concordance and co-ordination of different economic subjects interests. Sources of conflicts of interests in the corporations of Ukraine are management imperfection, unscreened of shareholders' rights, absence of reliable machineries of registration and transition of ownership right, and linked, foremost, with the low level of corporate culture, by disparity of existent practice of corporate management to the generally accepted principles.

The main task of management by the conflicts of interests in corporation is taken to creation of effective machineries of processes control of interests balancing of interested persons, and at the level of integrated structures these tasks are complicated by the machineries of balancing interests not only interested in activity and each of the groups members, but also by balancing interests of the corporation members in the process of establishment and achievement by the structure general corporate purposes.

All mentioned above enables to do a conclusion that entered for today in our country methods of the state regulation of corporate relations in Ukraine have considerable variety. In opinion of the author of the article, this is conditioned first of all by the gradual embodiment of the marked methods of the state regulation, not very clear distributing of the proper plenary powers between the organs of executive power.

To do this task firstly we need to form an expressly definite aggregate of necessary and sufficient terms in relation to providing perfection of this process. The development of aggregate of factors of policy activation in the sphere of corporate relations regulation must be aimed on the exposuring and overcoming obstacles in relation to providing high-quality descriptions of its input.

\section{References}

1. Vinnic O.M., Shcherbina V.S. Joint-stock law: manual. - K.: Atica, 2000. - 544 p.

2. Zadihaylo D.V., Cibenco O.R., Nazarova G.V. Corporate management: manual. - H.: Espada, 2003. - 688 p.

3. Evtushevsciy V.A. Bases of corporate management: manual. - K.: Knowledge-press, 2002. -317 p.

4. Cashanina T.V., Sudarcova E.A. Joint-stock law: Pract. course. - M.: Infra-M, 1997. $-350 \mathrm{p}$.

5. Fedorenco V. G. Knowledge about Investing: Textbook. - 3-te publishing. K.:MAUP, 2004. - 480 p. 